\title{
The collection and analysis of job advertisements: a review of research methodology
}

\author{
Ray Harper
}

\begin{abstract}
An increasing number of research studies in LIS use job adverts as a data source to analyse and track changes to job skills and the employment market over time. This review of 70 research studies in LIS aims to provide an overview of key characteristics of existing research methods, and to suggest improvements which could be made to methods. The researcher analysed different aspects of each study using a quantitative approach, and noted salient features of each study's methodology. The review found that studies of job adverts in LIS are characterised by: large sample sizes often collected using purposive sampling; a lack of full pilot studies and ethical assessments; minimal use of inferential statistics and automatic text analysis; and minimal use of complementary empirical methods. Studies of job adverts could be improved by: fuller preparation of research methods, more sophisticated methods of analysis, and greater use of secondary empirical methods.
\end{abstract}

\section{Introduction}

There is a long history of studies which collect and analyse job advertisements in library and information science (LIS), with Starr (2004) describing it as a "timehonoured methodology". As early as the 1970s, studies in LIS were examining job adverts as a data source for research (Frame, 1972; Palmer, 1978; Genaway, 1978). The method has been increasingly used in LIS, and is arguably growing in popularity. In 2010, eight studies of this type were published in LIS (Bychowski et al., 2010; Han and Hswe, 2010; Kenechukwu, 2010; Kumar, 2010; Majid and Mulia, 2010; Reeves and Bellardo Hahn, 2010; Sanchez-Cuadrado et al., 2010; Wang et al., 2010).

A major motivation for studies which use job advertisements as data is to examine the changing nature of skills which are required in the workplace. In LIS, the issue of changing skills is a topical discussion, with an increasing diversity of job

\section{Author}

Ray Harper works as Planning Assistant in Planning and Governance Services at the University of Sheffield.

Email: r.harper@sheffield.ac.uk

Received 14 October 2011

Accepted 17 April 2012 
roles, and fundamental redefinition of information work (Broady-Preston, 2010; Fisher et al., 2005; Partridge et al., 2010). There has been longitudinal research into the changes to the LIS workforce, most notably the WILIS project in North America (Marshall et al., 2009).

Workplace skills and workforce issues are often associated with the initial training of LIS professionals. A common purpose of this type of study is to inform the design of curricula for initial training, particularly in LIS programmes in higher education. Studies of job adverts by Iyer (2009) and Payne (2008) are focused on outcomes which might benefit curricula.

The current employment environment is another driver for examining job adverts as research data. Studies of job adverts are particularly relevant to areas where job roles are increasingly non-traditional and not connected to a well-defined profession. Knowledge management, for example, has significant overlap with other disciplines and eludes occupational categorization (Vasconcelos, 2008).

There are arguably reduced job opportunities for library and information workers in the current economic climate. The collection and analysis of job advertisements is a method which provides data relevant to these issues, by providing a snap-shot of the current employment market.

\section{Researching job adverts as a method}

\subsection{Benefits of the method}

The method of analysing job adverts is attractive because the data are:

- easily accessible (Vieira da Cuhna, 2009; Schlee and Harich, 2010);

- organic and naturalistic;

- of practical support to job seekers (Beile and Adams, 2000; Cullen, 2000).

The method enables longitudinal comparison and documentation of historical trends (Albitz, 2002). Todd et al. (1995) and Vieira da Cuhna (2009) summarise the method as an indicator of change in the LIS profession. There is a strong argument that the collection of job adverts could produce a measurable and comparable set of research data capable of showing long-term changes to LIS job roles.

\subsection{Drawbacks of the method}

There are problems with using job adverts as research data. There are practical issues with using job adverts as research data. Croneis and Henderson (2000) point out that some jobs are not advertised externally, which means there is some data which may be unavailable for analysis. A logistical limitation to researching job adverts is that the volume of data can inhibit the effective analysis of data, with a "danger of over-saturation" (Pickard, 2007, 65).

The drawback of using naturalistic data is that there are numerous "uncontrollable variables" (Xu, 1996, 29). The quality of writing in job adverts is unpredictable and variable. Job adverts can be ambiguous, making them resistant to accurate analysis, and challenging to code. They can also reflect recruiters' ability to 
communicate through written language, rather than describing the actual job (Ahmed, 2005).

Job adverts may be written to reflect a desired future state, rather than a current reality. They can be viewed as qualitative data which reflect ideal values $(\mathrm{Xu}$, 1996). In practical terms, this may be because some job adverts are advertising newly created job roles.

Job adverts can be affected by environmental pressures. Equality legislation in the UK (notably the 2006 Employment Equality Age Regulations) ensures that employers are not allowed to specify the desired number of years of experience. The legislative dimension is complicated by the commercialization of the internet (McMillan, 2009). Job adverts could be seen as advertising tools which sell a 'product' (a paid employment position) in exchange for 'capital' value (the skills and competencies of the successful candidate).

The effect of uncontrollable variables is that data in job adverts can be resistant to comparative analysis, which diminishes the likelihood of fully synthesized findings. The negative effect of these variables contrasts with experimental methods like randomized controlled trials, which maintain tighter control over different variables.

In addition to uncontrolled variables, there is a problem that job adverts in isolation present a segmented and partial view of reality. Job adverts do not provide any data which indicates the skills which successful candidates actually possess nor do they demonstrate the actual skills deployed in a job. Shi and Bennett (2000) argue that further understanding is required of the gaps between descriptions in job adverts and the actual jobs.

There is therefore justified scepticism towards the notion that job adverts reflect reality (Davies, 2008). It is therefore valuable to be aware that different types of 'reality' could be reflected in job adverts. Job adverts could reflect reality in an objective sense; reality as it is perceived by the writers; or reality as it is actually experienced by LIS professionals.

To this ambiguity is added a further ambiguity in the definition of 'job adverts' as a data source. Definitions include:

- advertisements;

- historical documents;

- unobtrusive survey data.

The core categorization of job adverts is a critical factor which influences how the method is executed, and how different variables are taken into account. A perception of job adverts as historical documents may focus on environmental factors (like legislative compliance). In contrast, a definition of job adverts as advertisements may focus on the promotional content, and writing style. 


\subsection{Guidance on the method}

There has been little guidance on the collection and analysis of job advertisements. The methods deployed in data collection, sampling, and data analysis are generally derived from the accumulated practice of studies using this method.

There is a lack of consolidated guidance on the specifics of research design in studying job advertisements. This is in contrast to detailed research guidance on methods like questionnaires, interviews and focus groups in LIS (e.g. in both Pickard, 2007 and Powell and Connaway, 2004). It is notable that Denscombe's (2003) account of documentary data omits job adverts.

The lack of guidance applies to both the practical elements of the research (the process of data collection and analysis) and the theoretical aspects (ontological frameworks used in research design). The minimal guidance on the method can be a negative factor when the method is used, because it means that researchers are likely to repeat the errors which previous research has made. The lack of recognition for the method in research methods literature may lead to the perception of it as an 'amateurish' activity, rather than a genuine research method.

This paper seeks to address this gap by examining the existing body of research, and attempting to give some consolidated guidance.

In light of this, the purpose of this paper is to:

1. review the methods used in research studies which collect and analyse job advertisements;

2. identify where research methods could be improved by evaluating existing methods against research standards.

The focus is on those aspects of the method in which measurement is used. This review is valuable because it presents a detailed discussion of the method. This will benefit researchers and practitioners by supporting improved understanding and application of the method. This paper is relevant to researchers who are currently using this method, or who plan to use it in future.

\section{Methodology}

The researcher selected and analysed 70 research studies in LIS which used job advertisements as research data. The sampling was purposive and research studies were selected which:

- used the method of collecting and analysing job advertisements, and

- were published or written in LIS or similar disciplines (i.e. knowledge management and information systems).

A small number of studies were reported in several journal articles, meaning that including all journal articles would have led to duplication. This review therefore only included the more detailed of the articles published. This approach meant that papers by Kennan et al. (2006), Cullen (2002) and Cullen and Kavanagh (2006) were excluded. 
These studies were found using Library and Information Science Abstracts (LISA), Emerald Management Reviews, Web of Science and Google Scholar. The following search string was used:

(job OR position OR post) AND (announcement OR ad OR advert OR advertisement OR description) AND (analysis)[all in title or abstract].

The results of this basic search were enhanced by the addition of highly cited studies. The review therefore included some studies without the original search string in the title or the abstract (e.g. Cronin et al., 1993; Fisher et al., 2005).

It was felt that ethical issues were minimal, because the study did not directly involve human participants, and did not deal with sensitive issues.

Key information about each research study and characteristics of the methods used were entered onto a Microsoft Excel spreadsheet. This was used to identify salient features of the methods used in each research study. Numerical intervals were generated to summarize statistical data. The data analysis was conducted using descriptive statistics, which provide "a clear foundation for discussion and critique" (Denscombe, 2003, 237). A mean average and a median average were calculated for the number of job adverts in each study, and for the length of time that each study had been conducted for. A modal average was not possible, because the number of job adverts was unique to each study.

\section{Results}

\subsection{Overview of the studies}

A total of 70 studies on job adverts in LIS were analysed for this review. The full data set is available on request. Figure 1 provides detail on the number of studies by year of publication. This indicates that studies collecting job adverts have been conducted across different decades. There has been a clear increase in the number of these studies in LIS, with 46 studies (66\%) published between 2000 and 2010 inclusive.

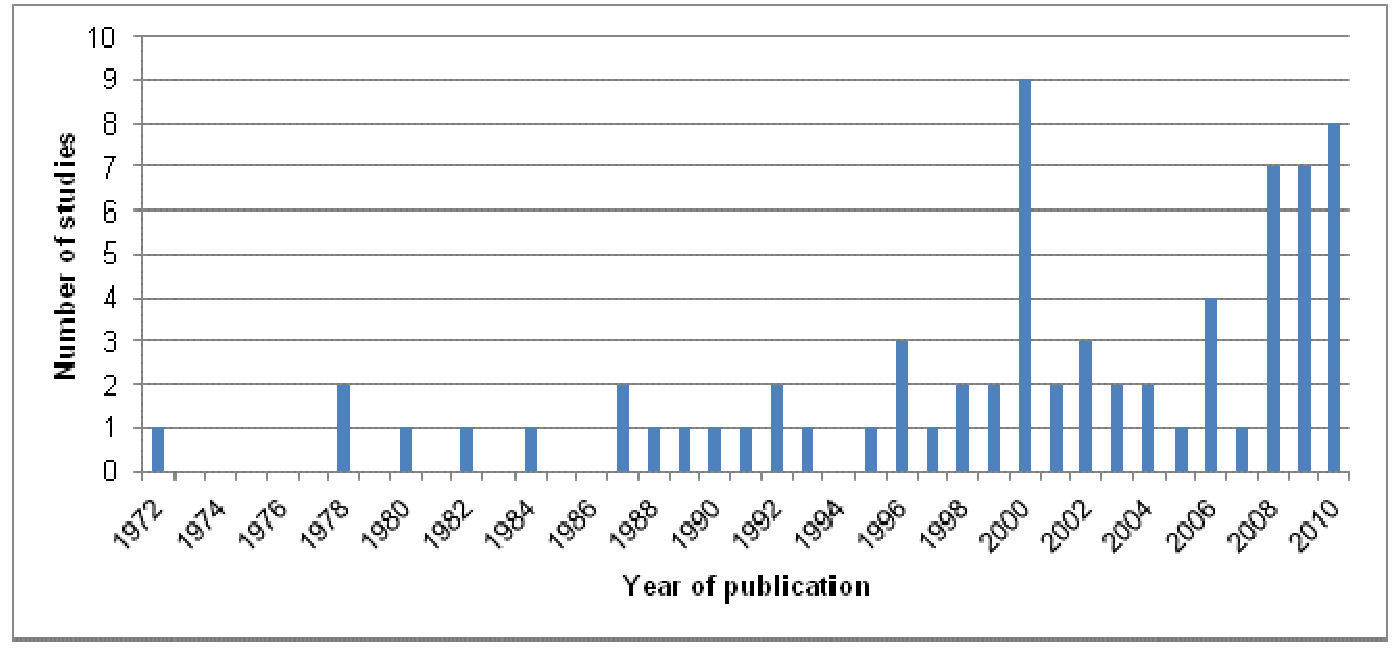

Figure 1: Job advert studies by year of publication. 
Most studies were conducted in English-speaking countries (Table 1). This may be due to the sources, or it could indicate a genuine trend in where research of this nature is conducted. $53(76 \%)$ studies of this nature were conducted in the USA, with only $6(9 \%)$ conducted in the UK. The studies conducted in the UK were those by Budd (1990), Davies (2008), Moore (1987), Morris (2001), Orme (2008) and Payne (2008).

\begin{tabular}{|l|c|c|}
\hline \multicolumn{1}{|c|}{ Country } & Number of studies & $\begin{array}{c}\text { \% of all studies } \\
(\mathbf{n = 7 0 )}\end{array}$ \\
\hline USA & 53 & $76 \%$ \\
\hline UK & 6 & $9 \%$ \\
\hline Australia & 5 & $7 \%$ \\
\hline Canada & 2 & $3 \%$ \\
\hline Ireland & 2 & $3 \%$ \\
\hline India & 2 & $3 \%$ \\
\hline South East Asia & 2 & $3 \%$ \\
\hline Spain & 1 & $1 \%$ \\
\hline South Africa & 1 & $1 \%$ \\
\hline Brazil & 1 & $1 \%$ \\
\hline Lithuania & 1 & $1 \%$ \\
\hline Estonia & 1 & $1 \%$ \\
\hline
\end{tabular}

Table 1: Geographic location of studies.

\subsection{Sample size}

A key element of a robust research method is the definition and selection of an appropriate sample. The definition of a sample naturally arises from the overall population. In studies of this type, the population is very large, chiefly because it consists of a high number of job adverts within a specific occupational area.

A study by Slaughter and Ang (1996) states that its population consisted of 20,000 job adverts, whilst a study by Koong et al. (2002) argues that the population of a study of job adverts can be theoretically infinite. A theoretically infinite population means that a sizeable sample will be collected.

This review found that:

- the majority of the studies used sample sizes between 1 and 199;

- taken together, the studies examined 37,970 job adverts in total;

- the mean number of job adverts examined was 575;

- the median number of job adverts studied was 236 ;

- the smallest sample size was 10 (Shank, 2006).

These findings exclude four studies which did not clearly state their sample size. There was a lack of transparency about the total sample size in studies by Wang et al. (2010) and Sanchez-Cuadrado et al. (2010). The results indicate that this is a 
research method which enables the collection of a large sample in a short time period. Figure 2 indicates that the majority of studies analysed more than 100 job adverts in their sample, suggesting that this could be an acceptable minimum sample size.

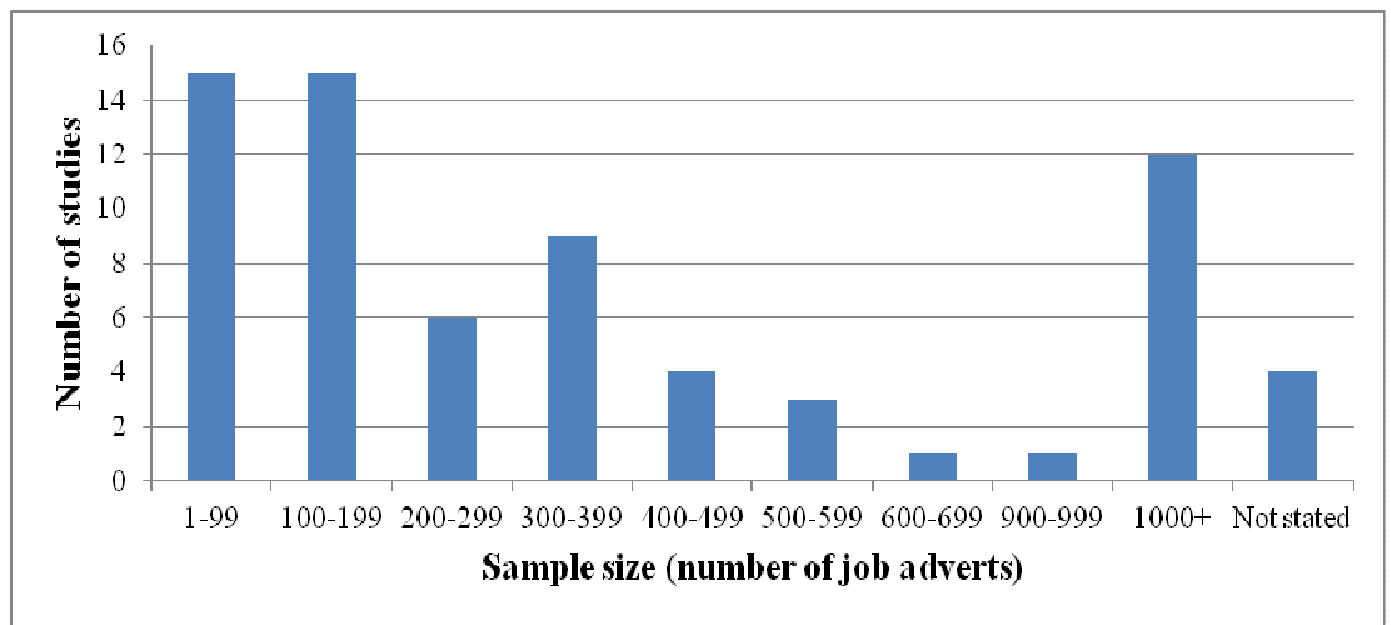

Figure 2: Sample sizes in studies of job adverts.

52 studies (the majority) took a purposive sampling approach. The purposive sampling techniques selected job adverts by:

- $\quad$ source (e.g. Park et al. (2009) took their sample from AUTOCAT jobs);

- date (e.g. Geromilos and Konsta (2008) selected jobs from 2006 and 2007);

- $\quad$ place (e.g. Cullen (2000) studied jobs in Ireland);

- type (e.g. Ferguson et al. (2008) studied only knowledge management jobs).

Researchers sometimes used more than one sampling criterion, taking their sample using a particular source that specialized in a particular type of job. In studies of health librarians, Glasgow and Foreman (1984) and Stroyan (1987) focused on samples collected from the Medical Library Association periodical.

An alternative approach was random sampling. This approach was taken in 12 studies (17\%). Surakka (2005) deliberately omitted data from every 5 th year in the date range, whilst Kinkus's (2007) study on project management skills examined 3 years' worth of data from a 10-year period.

\subsection{Length of sampling period}

The length of the sampling period varied significantly between studies (Table 3 ). 41 studies carried out sampling over less than 4 years. The shortest studies included a 3-month study by Clyde (2002) and an 8-week study by Marion et al. (2005).

13 studies (19\%) took samples from 10 years' worth of job adverts. Particularly long studies included a 10-year study by Croneis and Henderson (2002), and an 8year study by Han and Hswe (2010). 


\begin{tabular}{|l|c|c|}
\hline Length of sampling period & Number of studies & $\begin{array}{c}\text { \% of all studies } \\
(\mathbf{n = 7 0})\end{array}$ \\
\hline$<1$ year & 15 & $21 \%$ \\
\hline$\geq 1$ year and $<2$ years & 16 & $23 \%$ \\
\hline$\geq 2$ years and $<4$ years & 10 & $14 \%$ \\
\hline$\geq 4$ years and $<6$ year & 7 & $10 \%$ \\
\hline$\geq 6$ years and $<8$ years & 3 & $4 \%$ \\
\hline$\geq 8$ years and $<10$ years & 5 & $7 \%$ \\
\hline$\geq 10$ years & 13 & $19 \%$ \\
\hline Unclear & 1 & $1 \%$ \\
\hline
\end{tabular}

Table 2: Length of sampling period.

\subsection{Currency of data}

The sampling time period is significant when considering a key distinction in existing studies. In existing research, there are arguably two types of job advertisement collection and analysis. This distinction is important when evaluating the existing research methods.

The first is the collection of job adverts which are actually being used at the time of collection. This approach means that the data are collected at the time when a job advert is active in the public domain. 29 studies (41\%) collected job adverts which were current.

Studies using current job adverts require prompt data collection. In a study of health information professionals, Davies (2008) notes that the average advertising time for a job was 17 to 23 days, demonstrating that there is a limited time window when data can be collected. This suggests the need for establishing regular census points to collect data.

\begin{tabular}{|l|c|c|}
\hline Currency of data & Number of studies & $\begin{array}{c}\text { \% of all studies } \\
(\mathbf{n = 7 0})\end{array}$ \\
\hline Current & 29 & $41 \%$ \\
\hline Historical & 26 & $37 \%$ \\
\hline Unclear & 15 & $22 \%$ \\
\hline
\end{tabular}

Table 3: Currency of data.

The second type is the collection of job adverts which are historical, and are not being used to advertise current positions. This approach means that data are collected from historical sources. 26 studies $(37 \%)$ collected job adverts which were historical.

It must be noted that the data on the currency of job adverts (Table 3) is based on the researcher's interpretation of the data presented in studies. Most studies did not explicitly make a distinction between these different forms of data collection. 


\subsection{Pilot studies}

A minority of studies (8) explicitly described the use of pilot studies. These include studies by Park et al. (2009) and Lin and Ping (2008). Studies conducting pilot studies tended to focus on testing and developing procedures for coding data. These included test coding of 10 job adverts by Mathews and Pardue (2009), and test coding of 55 job adverts by Park et al. (2009). 62 studies (89\%) did not include a description of any pilot study or testing procedure.

\subsection{Ethical considerations}

Most studies reviewed for this article did not explicitly refer to ethical issues. Only Detlefsen (1992) explicitly considered the ethical dimensions of the research. This consisted of a footnote which explained that "for reasons of confidentiality, all libraries whose advertising is quoted in this article have been described generically" (Detlefsen, 1992, 196).

\subsection{Complementary methods}

It is a common standard that research should draw on multiple data sources to ensure credibility through 'triangulation'. The majority of studies did not use different sources of data, and focused on the collection of job adverts as the main method of investigation (Table 4).

To some degree, the results of the present study reflect its search strategy, which prioritized studies which explicitly used job adverts as a source of research data. The author recognises that this search strategy may have biased these results towards studies solely investigating job adverts. The data on complementary methods must be viewed in this light.

The analysis of complementary methods excludes literature reviews, which are not always regarded as an empirical research method. 57 studies $(81 \%)$ did not explicitly refer to complementary methods. It is therefore rare for studies on job adverts to carry out additional data collection. The implied consensus of existing research is that studies do not require an additional data collection method.

\begin{tabular}{|l|c|c|}
\hline $\begin{array}{l}\text { Complementary empirical } \\
\text { methods used }\end{array}$ & Number of studies & $\begin{array}{c}\text { \% of all studies } \\
(\mathbf{n = 7 0 )}\end{array}$ \\
\hline None & 57 & $81 \%$ \\
\hline Questionnaire survey & 9 & $13 \%$ \\
\hline Follow-up planned & 3 & $4 \%$ \\
\hline Survey of education programs & 3 & $4 \%$ \\
\hline Interviews & 1 & $1 \%$ \\
\hline
\end{tabular}

Table 4: Complementary empirical methods.

Complementary empirical methods included:

- interviews and a survey questionnaire (Cronin et al., 1993);

- a survey of knowledge management courses (Ferguson et al., 2008); 
- a survey of successful candidates (Willard and Mychalyn, 1998);

- a survey of courses accredited by the American Library Association (Kinkus, 2007).

\subsection{Analysis of data}

There are many ways to analyse and synthesize data, whether it is collected from one source or several. The importance of analysis is emphasised by Janesick (2000) who argues that time allocated for data analysis should be "equal to time in the field" (Janesick, 2000, 86).

Content analysis, a systematic technique of segmenting data into describable linguistic units, is often used in these types of study. This is a commonly used technique discussed in depth both within and beyond LIS discipline, with wide body of guidance to support its application to research (Krippendorff, 2004; White and Marsh, 2006).

A key element of content analysis is to 'code' data in a way which will categorize it. The simplest way to do this is to locate words in a job advert, and to provide a count of occurrences. In a study of the project management skills of librarians, Kinkus (2007) carried this out through utilising the 'Find' tool in Microsoft Word. A more advanced approach is to examine the co-occurrence of words, an approach taken by Sanchez-Cuadrado (2010) and Marion et al. (2005). There are different options for storage and analysis of coded data, with Deeken and Thomas (2006) using Microsoft Access to analyse their coded data.

The vast majority of the studies $(67=96 \%)$ carried out coding manually, with one or more people reading the adverts and extracting key themes. Slaughter and Ang (1996) had two coders; Beile and Adams (2000) had three. Studies typically had only one coder.

An alternative to manual coding is to deploy text analysis software to extract information about content. This can be done using a coding frame which is preestablished by a researcher. Studies of job adverts have deployed SimStat and Wordstat software (Marion et al., 2005) and QDA miner (Sanchez-Cuadrado, 2010). Only 3 studies (4\%) used automatic coding, which suggests that there is scope for further use of automatic text mining in job adverts in future research.

In light of the large volumes of data which research of this type can generate, inferential statistical analysis is a possibility. The large sample sizes mean that the application of inferential statistical techniques could be used to identify underlying patterns. Only 18 studies did so. The methods used included:

- $\quad \chi^{2}$ test (Alonso-Regaldo and Van Ullen, 2010; Reser and Schuneman, 1992; Smith, 1997; Xu, 1996)

- Scott's pi (Mathews and Pardue, 2009)

- multi-dimensional scaling (Marion et al., 2005; Park et al., 2009)

- coefficient tests (Hall-Ellis, 2006; Slaughter and Ang, 1996) 


\section{Discussion}

\subsection{Sample}

Studies which collect and analyse job adverts are likely to produce a large sample size in a short time period. This is primarily due to the accessibility of the data, without the difficulties of low response rates or of obtaining informed consent (as with interviews and questionnaires). The large sample sizes are an opportunity and a threat. Large samples have the clear benefit of leading to a more accurate picture of the overall population (Pickard, 2007).

There are drawbacks to a large sample size. A major problem is that analysis cannot be carried out in depth, because the data are atomistic. This means that the loss of contextual meaning is likely. The precise process of how data collection is conducted is vital to managing a large sample, and in being able to enable replication, which is "the most important form of reliability" (Krippendorff, 2004, 18). A good example of a rigorous data management process is in Cali's (2000) study, which used a data collection sheet to record data.

The preference in studies of job adverts is for purposive sampling. The obvious disadvantage of purposive sampling is that there is a strong likelihood of bias. In contrast, the advantage of random sampling is that it reduces potential bias in sample selection. It also supports the efficient analysis of historical job advert data, which could be expensive and time-consuming to analyse in detail.

\subsection{Currency of data}

A key distinction between studies is those which collect current data (collecting data as it becomes available) or historical data (conducting an historical analysis of existing documents). The key differences are outlined in Table 5.

Various studies emphasize that online job adverts are not archived for later use (Kenechukwu, 2010; Mathews and Pardue, 2009; Reeves and Bellardo Hahn, 2010). The lack of centralised online archiving presents a challenge for both types of study. Although it may be possible to retrieve archived online job adverts after their closing dates, most job adverts would be removed from websites within a limited time period. The disadvantage of conducting a study on current jobs is that data need to be collected at least fortnightly. This means that census points for data collection should be set.

This may suggest that the method of collecting job adverts currently being advertised could be seen as distinct from document analysis. Document analysis would normally rely on the durability of its sources (Hodder, 2000). In contrast, the collection of job advertisements may involve data which are only available for a short period of time.

Current job adverts are characterised by impermanence, with a limited time window for data collection. This causes a problem in relation to the theory that job adverts can be used as stable indicators. Without a systematic approach to archiving, retrospective analysis of historical job adverts will become increasingly difficult. This suggests a need for the development of a profession-wide strategy for archiving job adverts, and capitalizing on the information that they contain. 


\begin{tabular}{|c|c|c|c|}
\hline \multicolumn{2}{|c|}{ Characteristics } & Historical data & Current data \\
\hline \multirow{2}{*}{ 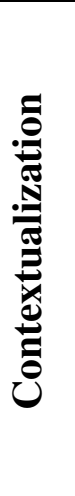 } & $\begin{array}{l}\text { relation to } \\
\text { complementary } \\
\text { methods }\end{array}$ & $\begin{array}{l}\text { difficult to use alongside } \\
\text { other research methods, } \\
\text { since data is not current }\end{array}$ & $\begin{array}{l}\text { may be used alongside } \\
\text { other research methods } \\
\text { (e.g. data collection from } \\
\text { successful candidates) }\end{array}$ \\
\hline & $\begin{array}{l}\text { long-term } \\
\text { significance }\end{array}$ & $\begin{array}{l}\text { may be explained in terms } \\
\text { of broader historical } \\
\text { patterns (e.g. employment } \\
\text { trends) }\end{array}$ & $\begin{array}{l}\text { difficult to explain in } \\
\text { terms of broader } \\
\text { historical patterns (e.g. } \\
\text { employment data may be } \\
\text { published many months } \\
\text { later) }\end{array}$ \\
\hline \multirow{2}{*}{ 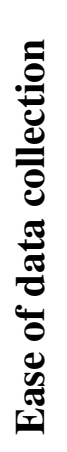 } & $\begin{array}{l}\text { published } \\
\text { online }\end{array}$ & $\begin{array}{l}\text { difficult to collect because } \\
\text { online data of this kind is } \\
\text { rarely archived }\end{array}$ & $\begin{array}{l}\text { easy to collect from } \\
\text { different sources, but } \\
\text { there are time pressures } \\
\text { (i.e. jobs often advertised } \\
\text { in only } 1-2 \text { week } \\
\text { windows) }\end{array}$ \\
\hline & $\begin{array}{l}\text { published in } \\
\text { print }\end{array}$ & $\begin{array}{l}\text { easy to collect because } \\
\text { printed data of this kind is } \\
\text { often archived }\end{array}$ & relatively easy to collect \\
\hline \multicolumn{2}{|c|}{ Creation of data } & data pre-exists study & $\begin{array}{l}\text { data are made available } \\
\text { as the study takes place }\end{array}$ \\
\hline \multicolumn{2}{|c|}{ Bias } & $\begin{array}{l}\text { problem of different } \\
\text { historical interpretations }\end{array}$ & $\begin{array}{l}\text { problem of current } \\
\text { perceptions }\end{array}$ \\
\hline \multicolumn{2}{|c|}{ Relevance } & historical interest & current interest \\
\hline
\end{tabular}

Table 5: Comparison of current and historical data collection.

\subsection{Pilot studies}

This review found that a minority of studies tested or piloted their methods. Any testing tended to focus on the coding process. An advantage of testing the process of analysis is to establish key themes which emerge in each document, valuable because a coding frame is essential for both manual and automatic coding. A pilot study also offers a valuable practical test of the method, enabling refinement of the data collection procedure (Bryman, 2004).

Where testing was conducted, this rarely focused on the searching stage of the research. This would be a beneficial step, particularly given the importance of transparency around data collection. A non-LIS study by Robinson et al. (2010) on cookery-related jobs involved a week of searching online sources to identify the best sources, and test search keywords.

It is possible to speculate as to why studies of job adverts did not generally use pilot studies. One possibility is that researching job adverts is a method which is not seen to be as important as other methods, and therefore to require fewer tests. A second possibility is that the categorization and coding of job adverts are 
viewed as unobtrusive document analysis, and therefore as a neutral activity for which testing is not essential.

\section{$5.4 \quad$ Ethics}

Like pilot studies, ethical considerations are linked to the definition of what a 'job advert' is. Cali (2000) argues that analysing job adverts is a form of unobtrusive observation which does not harm or affect the participant. If this is accepted, then ethical issues (confidentiality and consent) could be seen as relatively unimportant. This would explain the general absence of explicit reference to ethical issues in studies of this nature.

It could be argued the treatment of ethics would be different if the collection and analysis of job adverts is viewed as a form of covert observation. The unwitting 'participants' would be those organisations advertising positions, thus providing the data for a study. Outside LIS, Bennett (2002) and Clark (1995) acknowledge that job adverts are likely to contain names of 'contact points', who can be contacted by job applicants. It is therefore valuable to consider anonymizing names of organizations to preserve confidentiality. This would be consistent with Pickard's (2007) suggestion that researchers should avoid use of identifying data.

This would require greater caution over obtaining informed consent, and fully informing participants of the study. This would raise the separate issue of whether job advertisements should be destroyed after they have been analysed (standard practice with data from questionnaires and interviews).

If job adverts are seen as adverts, there could be a debate over whether organisations might regard job adverts as part of their commercial 'brand' or intellectual property. Creswell's (2009) argument that the ownership of data determines ethical status suggests that researchers should seek consent from the organizations which originally created the job adverts. Legislative compliance is connected to this, with some organisations having 'terms of use' applying to their web-pages.

Ethics in research goes beyond interaction with research participants. Research ethics can include documenting data collection procedures in detail, establishing trust between the researcher and participants, and demonstrating a clear benefit for participants (Creswell, 2009). This review suggests that the status of ethics in the method is not a marginal issue, but is arguably central to the establishment of a robust job advert methodology.

\subsection{Complementary methods}

Most studies of job adverts did not use complementary methods. Such methods of data collection and analysis should be used, because the analysis of job adverts can be a flawed method (see section 2.2). There is a risk that the application of content analysis may discard the data's contextual meaning. Job adverts do not intrinsically explain the numerous variables which influence their content.

This strengthens the case for a more rounded understanding of the life-cycle of job adverts in terms of their production, exchange and consumption. Hodder's (2000) perspective on 'material culture' views documents as cultural artefacts, 
which are created in a specific historical context. It may be beneficial to examine the original production of job adverts, how these documents are perceived by job seekers, and how job adverts are used after fulfilling the purpose of attracting applications.

Studies of job adverts could be more fully contextualized through the collection of complementary data. It may be useful to investigate:

- $\quad$ skills successful candidates actually had (suggested by Todd et al., 1995);

- job descriptions of existing employees and how these compare with the reality of their tasks (explored in a study by Levin and Weiss-Gal, 2009);

- intangible qualities which make candidates successful in job applications.

The necessity for a holistic approach to data collection suggests that researchers could engage more with organizations from the outset. This would enable complementary methods, and ensure that the research outcomes have greater reach. There is evidence suggesting that greater engagement with key 'stakeholders' may result in research activity having more impact (Hall, 2011).

The general absence of complementary methods may be due to a perception that other methods (e.g. questionnaires) are more burdensome to conduct. The reason for this may be that these methods directly involve human participants, with a standard requirement to gain ethical approval. Methods involving human participants can be more practically difficult, with a need to chase up questionnaires, organise appointments for interviews, and transcribe vast quantities of spoken text. Researchers collecting and analysing job adverts might be dissuaded from complementary methods because of these greater practical difficulties.

A connected problem is that the collection and analysis of job adverts does not have a natural follow-up method. In contrast, a method like a questionnaire survey can be naturally followed up with identification of interview participants through the initial data collection method. This reinforces the argument for a greater link to organizational context from the outset, which would enable more natural follow-up methods.

\subsection{Analysis}

This review has found that the analysis of job adverts varies between studies. The root cause for varied approaches to analysis is the variation in the definition of the data 'unit' to be analysed. As job advertisements cannot be neatly categorised as a single data 'type', the analyses to which they are subjected varies between studies.

Manual coding is the preferred method of coding job adverts. The advantage is that a human reading of an advert may ensure that words are analysed in terms of their context as well as their frequency. A major disadvantage is that manual coding of a vast data set is time-consuming. This may lead to the problem of biased or inconsistent coding, particularly if data are not cross-coded effectively.

A minority of studies used automatic methods of analysing data. This is notable in light of the increasing use of automated analysis tools in social sciences (like 
Nvivo). The general absence of automatic text analysis may be because a number of studies are conducted by practitioners, who may not have access to sophisticated text mining tools (unlike researchers working within universities).

The advantages of using textual software analysis are that it can be quicker than manual coding, and can efficiently consolidate a large amount of data. This is of particular relevance to studies of job adverts, acknowledged to be a labourintensive method (Cronin et al., 1993). Disadvantages include a loss of contextual meaning, and the high cost (Weitzman, 2000).

The dearth of automatic textual analysis methods is paralleled by the minority of studies deploying inferential statistics. There is no clear evidence for the exact reasons, although it is possible to speculate as to the underlying causes. These might include problems with:

- knowledge and experience of statistics;

- personal confidence in using statistics;

- access to statistical analysis tools.

The minimal use of inferential statistics is surprising given that large sample sizes have greater potential for being analysed using statistical tests. There is scope for future studies to attempt a 'meta-analysis' of the statistics used in previous studies, or to conduct a detailed critique of the different statistical methods used (Powell and Connaway, 2004).

\section{Limitations}

This review provides relatively superficial data, and does not fully delve into the textual features of each study which used job advertisements as research data. A major flaw with using quantitative data to review research methodology is that this is not a rounded approach. Powell and Connaway (2004) argue that quantitative surveys (of which this review could be regarded as a type) do not permit causal inferences.

The 'quality' of research methods cannot necessarily be measured by a simple count or category. In particular, the use of ontological frameworks in research resists quantitative analysis, because these can be difficult to classify. A major flaw of this review is that it does not examine theoretical frameworks which may underpin studies of job adverts.

\section{Conclusion}

\subsection{Summary}

This review found that studies of job adverts have become prevalent in LIS research in recent years. Numerous studies have been conducted in the USA, while far fewer studies have been conducted in the UK.

The methods deployed in studies of job adverts in LIS are characterised by:

1. large sample sizes;

2. purposive sampling; 
3. a lack of pilot studies;

4. minimal engagement with ethical issues;

5. few complementary methods;

6. minimal use of inferential statistics;

7. minimal use of automatic text analysis.

Despite the long history and large volume of studies examining job adverts in LIS, the method is at an early stage in its development. This review is valuable because it provides a quantitative overview of this research method, in a form which can highlight key insights for researchers. It is anticipated that this review will support the improvement of the method, and enable future researchers to conduct research into job adverts with more rigour.

The strongest aspect of the studies on job adverts is the collection of a large sample of data in a relatively short space of time. This may explain why the method is increasingly deployed in LIS as an efficient way to investigate trends and patterns in the LIS employment market.

The weakest area of methodology is the general absence of complementary empirical methods in studies of this type. There are a number of drawbacks to the collection and analysis of job adverts, which mean that complementary empirical methods would be beneficial.

\section{$7.2 \quad$ Weaknesses}

There are significant difficulties with a large sample of data, with a risk that the data will not be fully exploited. The minimal use of inferential statistics and of automatic text analysis in these studies demonstrates that there is further potential for deploying more sophisticated ways to analyse textual data in job adverts.

The preparation phase of some studies lacks methodological rigour. This is shown through a lack of engagement with ethical issues, and minimal use of pilot studies. Although engagement with ethical issues in this type of research is not essential, there are areas where greater consideration of ethics would be beneficial. Applying ethics more rigorously could enable direct engagement with organisations, acknowledged to be a benefit by McKinnell Jackobson and Armstrong (1996).

The minimal use of pilot studies is concerning, particularly in light of the large sample sizes and that samples are typically analysed through manual coding. There is a high margin for errors in collecting, and coding data, which may be better managed through detailed testing of research instruments.

\subsection{Underlying problems}

There are three underlying problems which can affect the methods deployed in studies of this type. Firstly, there is a general ambiguity over the type of 'data' job adverts can be classified as. This is often the root cause for the lack of thorough preparation and analysis of data samples. The ethical use of data, and the most appropriate methods of analysis, directly depends on the definition of job 
adverts. Although this review has indicated the different data types which job adverts could be defined as, this is probably best defined by researchers. Researchers could therefore improve research methodology by defining job adverts as a particular type of data from the outset. This would enable methodology to be shaped in a way which coheres with the definition.

Secondly, there is little acknowledgement of the key distinction between sampling methods which collect current job adverts, and those which collect historical job adverts. There are subtle but important differences in the particular methodological challenges faced by the two types of study (see Table 5). Future research could ensure greater clarity over which type of job adverts are being collected, which would support a more holistic consideration of methodological issues.

Thirdly, job adverts only represent a small part of the phenomenon being investigated. A job advert forms part of a reality which is recorded and codified in documents. However, a job advert does not necessarily reflect the 'reality' of jobs as it is perceived and experienced by LIS professionals, or the 'reality' which can be objectively verified. There is a strong case for a holistic re-examination of the method, through a hermeneutic perspective, so that a wider range of experiences and perceptions can be investigated.

\subsection{Future research}

Future research studies of job adverts could use more comparative methods to support fuller contextualization. It would be possible to benchmark the data on job adverts in LIS with those in other disciplines. There are studies on job adverts in fields including:

- cookery (Robinson et al., 2010);

- operational research (Mar Molinero and Xie, 2007; Sodhi and Son, 2010);

- leadership (Den Hartog et al., 2007);

- marketing (Schlee and Harich, 2010);

- human resources (Redman and Mathews, 1995).

In light of the large number of LIS studies, there is an opportunity to conduct a meta-analysis or systematic review to synthesise key findings. This could support the consolidation of much-needed research guidance in this area. A strand of meta-analysis might involve synthesizing different sets of statistics.

There is an obvious difficulty in measuring the complexities of job skills and the employment market with a compound 'indicator'. From a policy perspective, this review could act as a catalyst for a discussion over whether job advertisements can be perceived as reliable indicators of job skills and the employment market. There is scope for a detailed investigation into the feasibility of using job advertisements as longitudinal indicators of job skills.

A key element of this would be to consider the benefits of establishing a centralised repository of LIS job adverts. Material for this could be obtained from websites like LISJobsnet (CILIP), jobs.ac.uk, NHS Jobs, and the BIALL jobs 
board. A development like this could enable more collaboration between researchers and recruiting organisations. This would have the beneficial sideeffect of enabling more opportunities for complementary methods to be applied in organizational contexts. Haggar-Guénette's (1989) study of Canadian employment trends examined job advertisements which were available in a 'helpwanted index'.

A similar centralized resource in the UK could:

- standardize the process of saving job advertisements;

- act as a central 'data hub' for researchers;

- support consistent tracking of job adverts over long time periods;

- support robust meta-analysis of job advert data.

It is hoped that this review will be the start of a rigorous examination of the method, enabling various improvements in the process. Table 6 assesses the strength of current research, and suggests concrete actions for future studies in this area. 


\begin{tabular}{|c|c|c|c|}
\hline $\begin{array}{l}\text { Methodological } \\
\text { feature }\end{array}$ & $\begin{array}{c}\text { Quality in } \\
\text { current } \\
\text { research }\end{array}$ & Good examples & Suggested actions \\
\hline sample size & good & $\begin{array}{l}\text { Xu and Chen (1999) } \\
\text { White }(2000) \\
\text { Clyde (2002) }\end{array}$ & $\begin{array}{l}\text { 1) collect a } \\
\text { minimum sample } \\
\text { of } 100 \text { job } \\
\text { adverts }\end{array}$ \\
\hline $\begin{array}{l}\text { sampling time } \\
\text { period }\end{array}$ & good & $\begin{array}{l}\text { Morris (2001) } \\
\text { Majid and Mulia } \\
\text { (2010) } \\
\text { Davies (2008) }\end{array}$ & $\begin{array}{l}\text { 2) collect a sample } \\
\text { over a minimum } \\
\text { of } 6 \text { months }\end{array}$ \\
\hline $\begin{array}{l}\text { ethical } \\
\text { considerations }\end{array}$ & poor & Detlefsen (1992) & $\begin{array}{l}\text { 3) anonymize } \\
\text { identifying data } \\
\text { 4) obtain consent } \\
\text { from } \\
\text { organizations }\end{array}$ \\
\hline $\begin{array}{l}\text { complementary } \\
\text { methods }\end{array}$ & poor & $\begin{array}{l}\text { Cronin et al. (1993) } \\
\text { Ferguson } \text { et al. }(2008) \\
\text { Kinkus (2007) }\end{array}$ & $\begin{array}{l}\text { 5) ensure greater } \\
\text { engagement with } \\
\text { organizations } \\
\text { 6) conduct follow- } \\
\text { up surveys of } \\
\text { candidates and/or } \\
\text { curricula }\end{array}$ \\
\hline $\begin{array}{l}\text { statistical } \\
\text { analysis }\end{array}$ & poor & $\begin{array}{l}\text { Marion et al. (2005) } \\
\text { Alonso-Regaldo et al. } \\
(2010) \\
\text { Mathews and Pardue } \\
(2009)\end{array}$ & $\begin{array}{l}\text { 7) analyse sample } \\
\text { using inferential } \\
\text { statistics }\end{array}$ \\
\hline $\begin{array}{l}\text { manual text } \\
\text { analysis }\end{array}$ & indifferent & $\begin{array}{l}\text { Slaughter and Ang } \\
\text { (1996) } \\
\text { Beile and Adams } \\
(2000)\end{array}$ & $\begin{array}{l}\text { 8) data to be coded } \\
\text { by more than one } \\
\text { person }\end{array}$ \\
\hline $\begin{array}{l}\text { automatic text } \\
\text { analysis }\end{array}$ & poor & $\begin{array}{l}\text { Sanchez-Cuadrado } \\
\text { (2010) } \\
\text { Marion et al. (2005) }\end{array}$ & $\begin{array}{l}\text { 9) use automatic } \\
\text { text analysis (e.g. } \\
\text { using nvivo) }\end{array}$ \\
\hline $\begin{array}{l}\text { pilot studies } \\
\text { and/or testing }\end{array}$ & poor & $\begin{array}{l}\text { Park et al. (2009) } \\
\text { Lin and Ping (2008) }\end{array}$ & $\begin{array}{l}\text { 10) test coding } \\
\text { method } \\
\text { 11) test search and } \\
\text { sourcing method }\end{array}$ \\
\hline
\end{tabular}

Table 6: Assessment of existing research and suggested actions. 


\section{References}

Ahmed, S. (2005) Desired competencies and job duties of non-profit CEOs in relation to the current challenges: through the lens of CEOs' job advertisements, Journal of Management Development, 24(10), 913-928.

Albitz, R. S. (2002) Electronic resource librarians in academic libraries: a position announcement analysis, 1996-2001, Portal: Libraries and the Academy, 2(4), 589-600.

Alonso-Regalado, J. and Van Ullen, M. K. (2010) Librarian for Latin American and Caribbean Studies in U.S. academic and research libraries: a content analysis of position announcements, 1970-2007, Library Resources and Technical Services, 53(3), 133-158.

Applegate, R. (2010) Job ads, jobs, and researchers: searching for valid sources, Library and Information Science Research, 32, 163-170.

Beile, P. M. and Adams, M. M. (2000) Other duties as assigned: emerging trends in the academic library job market, College and Research Libraries, 61(4), 336347.

Bennett, R. (2002) Employers' demands for personal transferable skills in graduates: a content analysis of 1000 job advertisements and an associated empirical study, Journal of Vocational Education and Training, 54(4), 457-476.

Broady-Preston, J. (2010) The information professional of the future: polymath or dinosaur? Library Management, 31(1-2), 66-78.

Bryman, A. (2004) Social Research Methods. $2^{\text {nd }}$ ed. Oxford: Oxford University Press.

Budd, J. (1990) Salaries of automation librarians: positions and requirements, Journal of Library Administration, 13(1-2), 21-29.

Bychowski, B. K. H., Caffrey, C.M., Costa, M. C., Sudhakaran, J. and Zhang, Y. (2010) Old words, new meanings: a study of trends in science librarian job ads, Issues in Science and Technology Librarianship, fall issue. URL: http://www.istl.org/10-fall/article1.html [accessed 01.09.2011].

Cali, J. R. (2000) Law firm librarian requirements: a content analysis of skills and qualifications. M.Sc. paper, [s.1.].

Clark, C. L. I. (1995) Content of advertisements for junior doctors: is there sufficient detail? British Medical Journal, 310(6978), 512-514.

Clyde, L. A. (2002) An instructional role for librarians: an overview and content analysis of job advertisements, Australian Academic and Research Libraries, 33(3), 150-167.

Creswell, J. W. (2009) Research design: qualitative, quantitative, and mixed methods approaches. $2^{\text {nd }}$ ed. London: Sage Publications.

Croneis, K. S. and Henderson, P. (2002) Electronic and digital librarian positions: a content analysis of announcements from 1990 through 2000, Journal of Academic Librarianship, 28(4), 232-237. 
Cronin, B., Stiffler, M. and Day, D. (1993) The emergent market for information professionals: educational opportunities and implications, Library Trends, $\mathbf{4 2}(2)$, 257-276.

Cullen, J. (2000) A review of library and information service job advertisements: what do they tell us about work in the Irish library sector? Journal of Information Science, 26(4), 278-281.

Cullen, J. (2002) The employment market for library and information management workers in Ireland, Library and Information Research, 26(83), 1726.

Cullen, J. and Kavanagh, A. (2006) Indexing change in LIS work: implications for recruiting managers, Library Management, 27(9), 600-605.

Davies, K. (2008) Job hunting in the UK using the internet: finding your next information professional role in the health care sector and the skills employers require, Health Information and Libraries Journal, 25, 106-115.

Deeken, J. and Thomas, D. (2006), Technical services job ads: changes since 1995, College and Research Libraries, 67, 136-145.

Den Hartog, D. N., Caley, A. and Dewe, P. (2007), Recruiting leaders: an analysis of leadership advertisements, Human Resource Management Journal, 17(1), 5875.

Denscombe, M. (2003) The good research guide for small-scale social research projects. $2^{\text {nd }}$ ed. Maidenhead: Open University Press.

Detlefsen, E. G. (1992) Specialists as professionals in research libraries: an overview of trends and an analysis of job announcements, Library Trends, 41(2), 187-197.

Ferguson, S., Hider, P., and Lloyd, A. (2008) Are librarians the ultimate knowledge managers? A study of knowledge, skills, practice and mindset, Australian Library Journal, February issue, 39-61.

Fisher, B., Hallam, G. and Partridge, H. (2005) Different approaches, common conclusions: the skills debate of the twenty-first century, New Review of Academic Librarianship, 11(1), 13-29.

Frame, R. R. (1972) Library salaries and vacancies as reflected in job adverts, Bowker Annual, 278-281.

Genaway, D. C. (1978) Barcoding and the librarian supermarket: an analysis of advertised library vacancies, Library Journal, 103(3), 322-325.

Geromilos, M. and Konsta, R. (2008) Librarians' skills and qualifications in a modern informational environment, Library Management, 29(8-9), 691-699.

Glasgow, V. L. and Foreman, G. (1984) Subject Expertise among MEDLINE searchers: results of a survey and analysis of job openings, Bulletin of MLA, 72(3), 257-261.

Gorman, G. E and Clayton, P. (2005) Qualitative research for the information professional: a practical handbook. London: Library Association. 
Haggar-Guénette, C. (1989) Job ads: a leading indicator? Perspectives on Labour and Income, $\mathbf{1}(2)$.

Hall, H. (2011) Impact as a dimension of research quality. Presented at:

Evidence-Based Library and Information Practice conference (EBLIP) $\left(6^{\text {th }}: 27-\right.$ 30 June 2011 : University of Salford).

Hall-Ellis, S. D (2006), Cataloguing electronic resources and metadata: employers' expectations as reflected in American Libraries and AutoCAT, 20002005, Journal of Education for Library and Information Science, 47(1), 38-51.

Han, M-J. and Hswe, P. (2010) the evolving role of the metadata librarian competencies found in job descriptions, Library Resources and Technical Services, 54(3), 129-141.

Hodder, I. (2000) The interpretation of documents and material culture. In: Denzin, N. K. and Lincoln, Y. S. (eds.) Handbook of qualitative research. London: Sage Publications. 703-715.

Iyer, H. (2009) A profession in transition: towards development and implementation of standards for visual resources management - part A, the organization's perspective, Information Research, 14(3).

Janesick, V. J. (2000) The choreography of qualitative research design: minuets, improvisations and crystallization. In: Denzin, N. K. and Lincoln, Y. S. (eds.) Handbook of Qualitative Research. London: Sage Publications. 379-399.

Kenechukwu, O. (2010) The changing professional image of librarians: focusing on the job positions of digital librarians in academic libraries in the United States of America. Master's dissertation, Oslo.

Kennan, M. A., Cole, F., Willard, P., Wilson, C. and Marion, L. (2006) Changing workplace demands: what job adverts tell us, Aslib Proceedings: New Information Perspectives, 58(3), 179-196.

Kinkus, J. (2007) Project management skills: a literature review and content analysis of librarian position announcements, College and Research Libraries, 68(4), 352-363.

Koong, K. S., Liu, L. C. and Liu, X. (2002) A study of the demand for information technology professionals in selected internet job portals, Journal of Information Systems Education, 13(1), 21-28.

Krippendorff, K. (2004) Content analysis: an introduction to its methodology. $2^{\text {nd }}$ ed. London: Sage Publications.

Kumar, B. (2010) Employability of library and information science graduates: competencies expected versus taught - a case study, DESIDOC Journal of Library \& Information Technology, 30(5).

Levin, L. and Weiss-Gal, I. (2009), Are social workers required to engage in participatory practices? An analysis of job descriptions, Health and Social Care in the Community, 17(2), 194-201. 
Lin, W and Ping, L. (2008) What do they want? A content analysis of Medical Library Association reference job announcements, 2000-2005, Journal of the Medical Library Association, 96(4), 378-381.

Majid, S. and Mulia, R. (2010). Competencies sought by knowledge management employers: content analysis of online job advertisements. In: Chu, S., Ritter, W. and Hawamdeh, S. (eds.) Managing knowledge for global and collaborative innovations. World Scientific Publications: Singapore. 317-326.

Mar Molinero, C. and Xie, A. (2007). What do UK employers want from OR/MS? The Journal of the Operational Research Society, 58(12), 1543-1553.

Marion, L., Kennan, M. A., Willard, P. and Wilson, C. (2005) A tale of two markets: employer expectations of information professionals in Australia and the United States of America. Presented at: IFLA General Conference and Council $\left(71^{\text {st }}: 14-18\right.$ August $2005:$ Oslo).

Marshall, J. G., Marshall, V. W., Craft Morgan, J., Barreau, D., Moran, B. B., Solomon, P., Rathbun-Grubb, S. and Thompson, C. A. (2009) Where are they now? results of a career survey of library and information science graduates, Library Trends, 58(2), 141-154.

Mathews, J. M. and Pardue, H. (2009) The presence of IT skill sets in librarian position announcements, College and Research Libraries, 70(3), 250-257.

Mckinnell Jackobson, C. and Armstrong, R. D. (1996) What information systems employers want: an analysis of job advertisement in the middle Atlantic states, Journal of Education for MIS, 5(1), 32-40.

McMillan, S. (2009) The challenge of applying content analysis to the world wide web. In: Krippendorff, K. and Bock, M. A. (eds.), The content analysis reader. London: Sage. 60-67.

Moore, N. (1987) The emerging employment market for librarians and information in the UK, Journal of Librarianship and Information Science, 19(1), $31-40$.

Morris, A. (2001), Knowledge management: opportunities for LIS graduates. Presented at: IFLA General Conference and Council $\left(67^{\text {th }}: 16-25\right.$ August 2001 : Boston, Mass.).

Orme, V. (2008) 'You will be...:' a study of job advertisements to determine employers' requirements for LIS professionals in the UK in 2007, Library Review, 57(8), 619-633.

Palmer, J. W. (1978) Changes in medical librarianship: a content analysis of job advertisements in the MLA News, 1961-1977, Bulletin of the Medical Library Association, 66(4), 464-466.

Park, J.-R., Caimei L. and Marion, L. (2009) Cataloguing professionals in the digital environment: a content analysis of job descriptions, Journal of the American Society for Information Science and Technology, 60(4), 844-857. 
Partridge, H., Menzies, V., Lee, J. and Munro, C. (2010) The contemporary librarian: skills, knowledge and attributes required in a world of emerging technologies, Library and Information Science Research, 32, 265-271.

Payne, H. (2008) Information management: a contemporary study of the discipline and the profession. M.Sc. (Econ.) dissertation, University of Wales, Aberystwyth.

Pickard, A. J. (2007) Research Methods in Information. London: Facet Publishing.

Powell, R. R. and Connaway, L. S. (2004), Basic research methods for librarians. $4^{\text {th }}$ ed. London: Libraries Unlimited.

Redman, T. and Mathews, B. P. (1995) Trends in recruitment: a ten-year retrospective view, The International Journal of Career Management, 7(2), 1016.

Reeves, R. K. and Bellardo Hahn, T. (2010) Job advertisements for recent graduates: advising, curriculum, and job-seeking implications, Journal of Education for Library and Information Science, 51(2), 103-119.

Reser, D. W. and Schuneman, A. P. (1992) The academic library job market: a content analysis comparing public and technical services. College and Research Libraries, 53(1), 49-59.

Robinson, R. N. S, Arcodia, C. V., Tian, C, and Charlton, P. (2010) Cookeryrelated employment vacancy advertisements and skills shortages, International Journal of Contemporary Hospitality Management, 22(4), 483-499.

Sanchez-Cuadrado, S. Morato, J., Andreadakis, Y. and Moreiro, J. A. (2010) A study of labour market information needs through employers' seeking behaviour, Information Research, 15(4).

Schlee, R. P. and Harich, K. R. (2010) Knowledge and skill requirements for marketing jobs in the $21^{\text {st }}$ century, Journal of Marketing Education, 32(3), 341352.

Shank, J. D. (2006) The blended librarian: a job announcement analysis of the newly emerging position of instructional design librarian, College and Research Libraries, 67(6), 514-524.

Shi, N. and Bennett, D. (2000) Information systems management positions: a market perspective, Work Study, 49(7), 275-284.

Slaughter, S. and Ang, S. (1996) Employment outsourcing in information systems, Communications of the ACM, 39(7), 47-54.

Smith, A. M. (1997) Internet skills: an analysis of position advertisements 19911995, Bulletin of Medical Library Association, 85(2), 196-198.

Sodhi, M. and Son, B.-G. (2010) ASP, the art and science of practice: skills employers want from operations research graduates, Interfaces, 38(2), 140-146.

Starr, J. (2004) A measure of change: comparing library job advertisements of 1983 and 2003, LIBRES, 14(2). 
Stroyan. S. (1987) Qualifications sought by employers of health sciences librarians, 1986, Bulletin of Medical Library Association, 75(3), 209-213.

Surakka, S. (2005) Analysis of technical skills in job advertisements targeted at software developers, Informatics in Education: an International Journal, 4(1), $101-122$.

Todd, P. A., McKeen, J. D. \& Brent, R. (1995) The evolution of IS job skills: a content analysis of IS job advertisements from 1970 to1990, MIS Quarterly, 19(1), 1-27.

Vasconcelos, A. C. (2008) Dilemmas in knowledge management, Library Management, 29(4-5), 422-443.

Vieira da Cunha, M. (2009) The information professional's profile: an analysis of Brazilian job vacancies on the internet, Information Research, 14(3).

Wang, H., Tang, Y., and Knight, C. (2010) Contemporary development of academic reference librarianship in the united states: a 44-year content analysis. The Journal of Academic Librarianship, 36(6), 489-494.

Weitzman, E. A. (2000) Software and qualitative research. In: Denzin, N. K. and Lincoln, Y. S. (eds.) Handbook of Qualitative Research. London: Sage Publications. 803-820.

White, G. W. (2000) Head of reference positions in academic libraries: a survey of job announcements from 1990 through 1999. Reference and User Services Quarterly, 39(3), 265-272.

White, M. D. and Marsh, E. E. (2006) content analysis: a flexible methodology. Library Trends, 55(1), 22-45.

Willard, P. and Mychalyn, J. (1998) New information management work in a changing world: an Australian survey, International Journal of Information Management, 18(5), 315-327.

$\mathrm{Xu}, \mathrm{H}$. and Chen, H.-L. (1999) What do employers expect? The educating systems librarian research project 1, The Electronic Library, 17(3), 171-178.

$\mathrm{Xu}, \mathrm{H}$. (1996) The impact of automation on job requirements and qualifications for catalogers and reference librarians in academic libraries, Library Resources and Technical Services, 40(1), 9-31.

\section{Acknowledgement}

The author acknowledges the contribution of his employer, University of Sheffield, in contributing to this research through access to electronic and library resources.

\section{Open access and copyright}

Library and Information Research is an open access journal. A freely available copy of this paper may be downloaded from the journal's website:

http://www.cilipjournals.org.uk/lir 
Copyright and associated moral rights in works published in Library and Information Research are retained by the author(s) but this paper may be used freely, with proper attribution, in educational and other non-commercial settings. 